\section{BASIL ANTHONY MOREAU (1799-1873) AND HIS PHILOSOPHY OF CHRISTIAN EDUCATION}

\section{Md. Shaikh Farid ${ }^{*}$}

\begin{abstract}
This article examines Basil Anthony Moreau's philosophy of education, and particularly his idea of Christian education. Moreau is the founder of the Congregation of Holy Cross that has been working on education and evangelization since 1853 in different countries of the world including Bangladesh. His philosophy of education plays a significant role in guiding and running Holy Cross educational institutions across the globe. Moreau's educational philosophy envisioned three aims for all students in Holy Cross education: to develop the necessary skills and knowledge to function in the world and the hereafter; to nurture an appreciation for individual responsibility and social connectedness to advance social justice issues; to stimulate those critical dispositions of mind and heart essential to the sustenance of a peaceful society. He had the vision to educate both the hearts and minds of Christian students to grow in Christ's love and make the world a better place. His views on education also have inspired Holy Cross
\end{abstract}

* Associate Professor, Department of World Religions and Culture, University of Dhaka, Email: sfarid@du.ac.bd education the pursuit of academic excellence within a family's atmosphere that binds the student, faculty, staff, and alumni. Although Holy Cross educators did not implement the specific teaching methods of Moreau in all of their institutions, Moreau's views laid the foundation of educational philosophy in Holy Cross education.

Key Words: Holy Cross, Moreau, Catholic Education, Christian Education, Educational Philosophy

\section{Introduction}

Basil Anthony Moreau was the founder of the Congregation of Holy Cross - a Catholic religious order of man and women working on education and evangelism in sixteen countries across the globe including Bangladesh. Moreau founded the Congregation in the aftermath of the French Revolution as a reaction to the Revolution and reviving Christianity through educating the Christian youths (Beiting, 2005; Bergeron, 1985; Giallanza, 1998; Jenkins, 2011). He had the vision to educate both the hearts and minds of Christian students to grow in Christ's love and make the world a better place. He also made his vision for education clear: "We shall always place education side by side with instruction; the mind will not be cultivated at the expense of the heart. While we prepare useful citizens for society, we shall likewise do our utmost to prepare citizens for heaven" (Circular Letters 36, 1849). Moreau's vision has inspired the Holy Cross education the pursuit of academic excellence within a family's atmosphere that binds students, faculty, staff, and alumni. His writings, particularly Christian Education, continue to shape the pedagogy of Holy Cross educational institutions around the world. This paper examines his life, works, and his philosophy of education in the light of the manuscript Christian Education and other writings. 


\section{Moreau: His Life and Works}

Basil Anthony Moreau was born in 1799, close to the end of the revolutionary period, into a devout Catholic family in Laigne-en-Belin, a small village in Le Mans, France (Barrosse, 1969; Catta \& Catta, 1955). Moreau started his formal schooling in a parish school. He started his theological and philosophical studies at Saint Vincent's Seminary in Le Mans and studied theology at the Seminary of Saint Sulpice and Issy in Paris. Later he joined in teaching and ministry in Le Mans (Barrosse, 1969; Catta \& Catta, 1955). From his childhood, Moreau developed a different attitude towards life and nourished a desire to became a priest-teacher and preaching the Gospel (Bergeron, 1985). Even from his childhood, he developed his missionary zeal within him.

The political, religious, and cultural contexts of France at that time of his birth are crucial to understanding Moreau's vision of education and founding the Congregation of Holy Cross (Fitzgerald, 1937; MacEóin, 2007). Moreau was born in France during a period of dramatic changes primarily due to the consequence of the Enlightenment and the French Revolution. His early life went through those political turmoil periods in France: the First Republic (1792-1804), First Empire of Napoleon (1804-1814), and the Restoration of the Monarchy (1815-1830) (Jenkins, 2011). Each of the socio-political changes in France, from the Revolution to the Third Republic in 1870, had impacted the life of Moreau; and the influences were evident in his works and the philosophy of his mission. Barrosse (1969) argued, "The French Revolution (1789-1799) formed the background to the life of Basil Moreau, who was born as it ended and grew up in its aftermath" (p. 1). Notably, the rise of secularism, the suppression of Catholicism and the
Church's activities encouraged him to revive the Catholic Church and its institutions, and French society in general.

France witnessed dramatic shifts in its religious landscape after the French Revolution in 1789. The French Revolution initiated a decade that asserted the religious liberty of its people. Religious issues were central to the Revolution. It attempted first to reform Catholicism and later than by replacing it with beliefs and rituals suitable for the nation that asserted liberty, equality, and fraternity- the holy trinity (Furet, 1996). The revolutionary government passed laws that severely undermined the Catholic Church's power over family life and education in France. In 1805, France passed a law that separated the state from the Catholic domination over it, which was considered a historic win of reason over fanaticism. Secularization and dechristianization were considered the result of the French Revolution (Crook, 2002). As a result, Catholicism substantially lost its power to influence and shape government policy and private beliefs, education, and family life.

Moreau desired to counter the hostility of French governments towards Catholicism and the Church, the emergence of secularism, and the de-Christianization of France. Thus, he gathered together a group of priests, brothers, and sisters, who would be in close ties in faith and mission, and dedicate themselves to the zeal of making God known, loved and served, and to disseminate the knowledge of salvation to others (Beiting, 2005; Jenkins, 2011). In 1837, Moreau founded the Congregation of Holy Cross. Armstrong (2007) noted: "The French Revolution bears an ironic responsibility for generating works of charity. To counteract the social effects of the late $18^{\text {th }}$-century uprising, numerous religious 
communities were founded in France, among them the Congregation of Holy Cross" (p. 218).

The religious order had chosen its name from Sante Croix (Holy Cross), a neighborhood in Le Mans, and their work would be a ministry of faith and education of youth (Barrosse, 1969; Bergeron, 1985; MacEóin, 2007). Moreau wanted to see his mission spread across France and abroad. Moreover, he wanted to include in his order all aspects of ministry, namely, preaching, teaching, and foreign missions. Therefore, he sent missionaries to different countries, including Algeria, the United States, Canada, and Bangladesh.

Besides the mission of evangelization in abroad, Moreau expanded the activities of Holy Cross in many places outside France hoping that he would get his desired recognition for the Congregation. While he was eagerly waiting for the official recognition from the Vatican, the Vatican offered the Congregation a new mission to East Bengal (Barrosse, 1969; Bergeron, 1985; Goedert, 1983). The offer served Moreau dual purposes: to expand his missionary activity to India, an opportunity to achieve the recognition of his congregation. In 1857, Moreau finally received the long-awaited recognition. The recognition of the Holy Cross from Rome came a few years after the acceptance of the Bengal mission (MacEóin, 2007; Timm, 2003).

As a devoted Catholic, he underscored the need for the restoration of Catholicism and the regeneration of his society. He thought that the significant work of the Holy Cross would be to educate the youths to help them to be good citizens both of the earth and heaven (Moreau, 1856). Moreau saw his effort as a work of resurrection, of reconstructing, specifically in the light of the social upheaval of his time. Moreau also added a missionary zeal to the congregation he founded, and it grew and expanded beyond the border of France (Catta \& Catta, 1955; Jenkins, 2011).

\section{Moreau's Philosophy of Christian Education}

Moreau was a scholar and priest; thus, he wrote both on education and mission. Moreau's vision of education was elucidated in his Circular Letters, a collection of letters written by Moreau and was compiled in 1984 by Joel Giallanza and Joel Grise, to the people of his religious congregation, and his unpublished manuscript, Christian Education, translated by Hunt and Blauvelt in 2001 (Beiting, 2005; Jenkins, 2011). Circular Letters were vital since they addressed the significant issues faced by his men working in different places in France and other countries. As the Superior of his religious congregation, he wrote and circulated more than two hundred letters to the members of Holy Cross. They addressed different issues, including temporal, spiritual, religious formation, mission, mission's work, and Moreau's own life (Grove \& Gawrych, 2014; Schmitz, 2007).

His approach and vision of education found in the Circular Letters have also been explained in his manuscript entitled, Christian Education. Christian Education provided guidelines to the members of his newly founded religious congregation, who were involved in founding schools and teaching. Although the book contains guidelines for educators in Holy Cross tradition, it is neither a book for school management nor an indepth explanation of the educational theory. Instead, his work is the educational philosophy of the Holy Cross, and one of mission and direction of his educational endeavor in Holy 
Cross tradition (Jenkins, 2011). The book also presents Moreau's understanding of the nature and purpose of Catholic education.

The manuscript consists of three parts: teachers and students, maintenance and direction of schools, and formation of students to the Christian life and the means to assure their perseverance. Part One is also subdivided into two chapters: teachers and their relationships with students; and students and student-teacher relationships. The main focus of Part One of Christian Education is to describe the qualities of an ideal Holy Cross educator. In Part One, he also explained the nine qualities that he thought are essential for being an effective teacher for youths. He considered that these qualities are necessary for Christian educators to be efficient teachers in the community. He mentioned the following qualities: faithfulness, zeal, knowledge, seriousness, vigilance, patience, prudence, gentleness, and firmness (Moreau, 1856). In Part Two, Moreau focused on the student's realities and how they might interact with educators. Part Three deals with religious teaching and the Christian formation of students.

Christian Education is a result of Moreau's reflection and thought on education based on the two essential realities of his life: his observation on education and teaching career, and his theological interpretation and understanding about human nature. The later might be understood as to how he considered human experience both as a believer and a Catholic. Moreover, his consideration of Catholic theology of human creation, which is reflected in the image of Creator, allowed Moreau to shed light on his pedagogy (Jenkins, 2011). Moreau viewed the act of educating as deeply personal which was about enhancing and deepening of personal understanding of the realities of human existence, being created and saved by almighty and loving God. He considered both the French educational model and traditional Catholic education were limited in scope and unfulfilling (Fitzgerald, 1937). In his writings, Moreau underscored the importance of creating a different kind of educational model based on his understanding of the relationship between God and humankind in the institutions founded by the Holy Cross tradition (Schmitz, 2007).

He advocated the concept of educating the heart and mind of students. He believed that education should include every aspect of an individual, including learning, spirituality, arts, and athletics. He also differentiated instruction and education. He viewed that education should include information, formation, and transformation of students, and preparing them for this earthly life and the Kingdom of God (Beiting, 2005; Walsh, 2001). He believed that knowledge without values was empty; therefore, he thought that society has a greater need for people of values rather than knowledgeable people (Moreau, 1856). Moreau (1856) noted: "Society has a greater need for people of values than it has for scholars. Knowledge itself does not bring about positive values, but positive values do influence knowledge and put it to good use" (p. 2). Moreau's (1849) Circular Letter 36 illustrates Moreau's vision and understanding of education. The statements quoted below are a foundational vision statement about education by Moreau, which is also widely known and frequently cited by the educators in Holy Cross (Jenkins, 2011). Moreau noted:

We can state in a word the kind of teaching we hope to impart. Even though we base our philosophy course on the data of faith, no one needs fear that we shall confine our teaching within narrow and unscientific boundaries...We do 
not want our students to be ignorant of anything they should know. To this end, we shall shrink from no sacrifice. We shall always place education side by side with instruction; the mind will not be cultivated at the expense of the heart. While we prepare useful citizens for society, we shall likewise do our utmost to prepare citizens for heaven (quoted in Giallanza \& Grise, 1984, p. 28).

Moreau (1856) firmly believed in Divine Providence and thought that everything which comes from God is based on the human-divine relationship. He explained the fundamental idea of his theological interpretation of the Christian life, relying on Divine Providence. He believed that all things are influenced and provided by God's plan. Therefore, in Christian Education, he explained how one should consider teaching as a special call from God. Moreau (1856) thus, wrote at the very outset of his book: "Since God alone provides the means for the successful accomplishment of any task, it seems evident that a person needs to be called by God to be an effective teacher"(p.4). Moreover, he regarded teaching as a challenging task and a divinely inspired responsibility, and without a call from God to teach no one would be able to accomplish everything that teachers face daily. Moreau (1856) expressed that Christian educators need to have a divine call from God which will permit them to "work towards building Christian values in the young as well as towards giving them the knowledge they need" (p. 4).

Moreau, being a teacher for many years and a leader of a group of priests and brothers, viewed teaching as a delicate but meaningful task. He thought that since teachers deal with different types of students: spoiled young people, students who have poor upbringings, introvert youths, unintelligent young people, self-centered young people, self-oriented young people, young people with and without integrity, the purpose is to remind educators that the teaching lies in the best approach to an individual student (Moreau, 1856). He preferred to have an educational atmosphere that is suitable for the necessity of every individual student (Jenkins, 2011). Moreau (1856) viewed that "It would be a mistake to open a school imagining that all the students will be alike in character and conduct. Providence varies its entire works...It will do little good then to use the same procedures in working with every student" ( $p$. 10). Realizing the different needs of every individual student, he thought that the most obvious hurdles for teachers are to address those needs. He also emphasized that teachers should have enough knowledge of subjects, and methods and skills to impart that knowledge to students (Moreau, 1856).

He thought that Christian education aims to prepare young students to be good citizens for the worldly life and the life hereafter. He urged teachers to be aware of the human condition to use every possible means to lead the hearts and minds of learners nearer to God. Thus, according to him, a well-ordered learning and teaching environment is a prerequisite instrument to achieve this supreme goal (Moreau, 1856). He mentioned the goal and mission of his educational effort in the preface of his book, Christian Education. Moreau (1856) noted:

May this short work on education, intended for use by those working in the schools associated with the Congregation, attain the end that I proposed to myself in composing it: the formation of the hearts of young people and the development of a positive response toward religion within them. I have always understood the education of youth to be only this, 
and I have always been convinced that the first duty of any teacher is to produce Christians...Christian education alone can return people to the belief in and practice of Christianity by inspiring positive values in the coming generations. (p. 2)

Moreau expected that the students should have a positive idea about religion. He wished to develop the hearts of students and instill them a positive attitude to religious practices. He considered it as a way to help youths in understating the reality of salvation (Jenkins, 2011). He also outlined how to address the formation of Christian students in their faith and how teachers can help them in lifelong practices of religion and bring them closer to Christ and God. He epitomized the centrality of the Christian faith as the fundamental goal of his educational mission. Moreau (1856) noted:

You have not yet learned how to make of them Christians conformed to Jesus Christ; nevertheless, such is the principal goal of your mission among the young. To what end would it serve the students to know how to read, write, calculate, and draw, or to possess some notions of history, geography, geometry, physics, and chemistry, if they were ignorant of their duties to God, to themselves and society... It is up to you, then, after the pastor and the parish, to teach all that to your students, and get them to practice it as much as is in your power. You will do this by teaching them the Catechism, bringing them to prayer. (p. 15)

He emphasized that the Holy Cross education should uphold traditions, but at the same time should be a model for excellence in the field of education. He also proposed that the Holy Cross schools should give priority to those who are most in need, and the teachers should provide extra help to mitigate those needs. Moreover, in his thinking of education, he stressed the concept of a family both in schools and the Congregation itself, modeling on the family of Jesus, Mary, and Joseph (Moreau, 1856). Therefore, within the Congregation, he included lay people to work and pray along with the members of Holy Cross, believing that inclusion of laymen and women together with Holy Cross missionaries in the process of educating the youths would enhance the development of all associated. Moreau's emphasis on the inclusion of lay religious people is still being practiced in the Holy Cross schools (Beiting, 2005; Walsh, 2001).

Moreau believed that the formation of a Christian life of students is a great responsibility for the teachers, which also required individual zeal for the practice of religion. To achieve this goal, teachers need to have faith; otherwise, students will lack faith. Moreau (1856) viewed that "If this faith is lacking in the teachers, it will also be lacking in their students, and there will be among them only a little or no piety, or routine piety"(p. 15). He also reminded his people that teaching is a lifelong task and a ministry and asked them to take it seriously and regarded education as a means to sanctify youths (Moreau, 1856). According to Moreau, the very act of teaching comes from zeal. Moreau (1856) viewed zeal "is the great desire to make God known, loved and served and thus to bring knowledge of salvation to others" (p. 5). One cannot be successful in Christian education without a sincere desire to guide others to God and salvation (Moreau, 1856).

His personal experience, both as a child and youth, had an impact on how he understood education and the availability of education for mass people. Moreau was born in the period of post-revolutionary France, and without any doubt, the social and political, religious upheaval impacted every aspect of his 
life and his thinking about education (Barrosse, 1969; Bergeron, 1985). He wrote his book, Christian Education, while he was trying to get the Papal approbation for his newly formed congregation and proclaimed the importance of faithbased education and primacy of faith in education. Moreover, Moreau, being a zealous missionary, had a strong desire to make God known, loved, and served and thus invited others to involve in his mission (Schmitz, 2007). Moreau also wanted to renew the Christian faith and rejuvenate the French society. He viewed education as the principal means to achieve the goal.

Although Moreau intended that those who are engaged in the education of Holy Cross would follow the approach of educating and teaching students he discussed in his writings, it did not happen as his writings were somehow ignored because of the internal politics and divisions in the administration of the Holy Cross in the late eighteen hundred sixties (Bergeron, 1985; MacEóin, 2007). The manuscript, Christian Education, was limited to the people of the Congregation of Holy Cross during their expansion of educational activities. It was translated into English for more than one hundred twenty years of its writing (Jenkins, 2011). Moreover, the congregation has founded educational institutions in a different political, social, and cultural setting that presented unique challenges for them, and prevented them from having a unified educational system prescribed by Moreau. Additionally, Holy Cross educators do not consider Christian Education as a blueprint or scripture for establishing an educational institution. Although they do not implement the desired teaching methods of Moreau in their institutions, it lays the foundation of educational philosophy in the Holy Cross education (Schmitz, 2007).

\section{Conclusion}

Moreau's educational philosophy envisioned three aims for all students in Holy Cross education: to develop the necessary skills and knowledge to function in the world and the hereafter; to nurture an appreciation for individual responsibility and social connectedness to advance social justice issues; to stimulate those critical dispositions of mind and heart essential to the sustenance of a peaceful society. Based on Moreau's educational philosophy the Holy Cross educational institutions also share three major characteristics: an unyielding commitment to academic programs for all students, regardless of their background; an inspirational ideology that guides educational activities in schools; a pervasive sense shared by both students and teachers. A constrained academic structure, a cooperative school organization, and an inspirational ideology are the major strengths that guide the operations of Holy Cross schools and colleges and contribute to their overall effectiveness (Bryk, Lee, \& Peter, 1993). These characteristics vitalize an educational philosophy that aims not only to influence what students know and can do but also the kind of people they will become.

\section{References}

Armstrong, P. C. (2007). Early 20th Century Education in the United States: The Role of the Brothers of Holy Cross. Catholic Education: A Journal of Inquiry and Practice, 11(2), pp. 218225.

Barrosse, T. (1969). Moreau: Portrait of a Founder. Notre Dame, Indiana: Fides Publishers, Inc.

Beiting, M. A. (2005). A Case Study: Archbishop Hoban High School's Journey to Coeducation. (Unpublished Doctoral Dissertation), The University of Arkon. 
Bergeron, H.P. (1985). Basil Moreau: Founder of the Congregations of Holy Cross (E. Swaile, Trans.). Rome: The Congregation of Holy Cross.

Bryk, A. S., Lee, V. E., \& Peter, B. (1993). Catholic Schools and the Common Good. Harvard University Press.

Catta, E., \& Catta, T. (1955). Basil Anthony Mary Moreau. Bruce Publishing Company.

Crook, M. (Ed.) (2002). Revolutionary France -1788-1880. Oxford: Oxford University Press.

Fitzgerald, G. M. J. C. (1937). Juxta Crucem: The Life of Basil Anthony Moreau, 1799-1873, Founder of the Congregation of Holy Cross and the Marianite Sisters of Holy Cross. New York: P.J. Kennedy.

Furet, F. (1996). The French Revolution 1770-1814. Oxford, UK: Blackwell.

Giallanza, J. (Ed.) (1998). A Simple Tool: The Mission and Message of Father Basil Moreau. Rome: The Congregation of Holy Cross.

Giallanza, J., \& Grise, J. (Eds.). (1984). Circular Letters of the Very Reverend Basil Moreau: Founder of the Religious of Holy Cross. Rome: The Congregation of Holy Cross.

Goedert, E. N. (1983). Holy Cross Priests in the Diocese of Dacca, 1853-1981. Indiana, USA: Province Archives Center.

Grove, K., \& Gawrych, A. (Eds.). (2014). Basil Moreau: Essential Writings. Notre Dame, Indiana: Ave Maria Press, Inc.

Jenkins, W. E. (2011). To Know, Love, and Serve God: The Characteristics of a Holy Cross School. (Unpublished Doctoral Dissertation), The University of San Francisco, San Fransisco.

MacEóin, G. (2007). Basil Moreau: Founder of Holy Cross. Notre Dame: Ave Maria.

Moreau, B. A. (1856). Christian Education. In B. S. Walsh (Ed.), Christian Education. Le Mans: Lanier and Company.
Schmitz, B. G. (2007). Christian Education by Venerable Basil A. Moreau, CSC: Vision, Instruction, Invitation. USA: The Holy Cross Institute.

Timm, R. W. (Ed.) (2003). 150 Years of Holy Cross in East Bengal Mission. Dhaka: The Congregation of Holy Cross.

Walsh, B. S. (2001). Called to Hope: Some Characteristics of a Holy Cross Educator. Retrieved from http://www.holycrossinstitute. org/sites/default/files/u11/called_to_hope.pdf.

This paper is based on his $\mathrm{PhD}$ dissertation on Holy Cross education in Bangladesh at the University of Hong Kong. 